\title{
Carcinoid Tumours of the Bronchus: A Series of Five Cases Seen at the Army Chest Unit
}

\section{Capt N A Hoad,}

MA, MRCP, RAMC

Specialist in Medicine

Col J Carson,

MB, FRCP, L/RAMC

Consultant in Charge

Army Chest Unit, Cambridge Military Hospital, Aldershot, Hants

SUMMARY: We have seen and treated five cases of carcinoid tumour of the bronchus over the last two years. All five have been serving soldiers. Their case histories are described and management and prognosis discussed.

\section{Introduction}

The majority of soldiers with unusual respiratory symptoms or chest X-rays are referred to the Army Chest Unit for investigation. We have recently seen five carcinoid tumours. It is important to diagnose these tumours early, not because of the risk of metastatic spread, but because appropriate early surgery can be curative and can preserve normal lung. A soldier so treated should have no respiratory insufficiency and should be able to continue his career in a normal medical category.

\section{Case Histories}

The case histories are summarised in Table 1.

Table 1

Tomography gave further information in cases (2) and (4); bronchial obstruction was seen and this was confirmed at bronchoscopy.

\begin{tabular}{|c|c|c|c|c|c|}
\hline Age & Presentation & $\begin{array}{l}\text { Chest X-ray } \\
\text { Findings }\end{array}$ & Bronchoscopy & Surgery & Results \\
\hline (1) 24 & $\begin{array}{l}\text { Recurrent } \\
\text { left lower } \\
\text { lobe pneumonia }\end{array}$ & $\begin{array}{l}\text { Persistent } \\
\text { left lower } \\
\text { zone } \\
\text { shadowing }\end{array}$ & $\begin{array}{l}\text { Tumour } \\
\text { obstructing } \\
\text { left lower } \\
\text { lobe bronchus }\end{array}$ & $\begin{array}{l}\text { Left lower } \\
\text { lobectomy }\end{array}$ & Good \\
\hline (2) 24 & $\begin{array}{l}\text { Recurrent } \\
\text { left upper } \\
\text { lobe pneumonia }\end{array}$ & $\begin{array}{l}\text { Persistent } \\
\text { left upper } \\
\text { zone } \\
\text { shadowing }\end{array}$ & $\begin{array}{l}\text { Tumour } \\
\text { obstructing } \\
\text { bifurcation } \\
\text { of left upper } \\
\text { lobe bronchus }\end{array}$ & $\begin{array}{l}\text { Left upper } \\
\text { lobectomy }\end{array}$ & Good \\
\hline (3) 25 & Asymptomatic & $\begin{array}{l}\text { Opacity } \\
\text { right mid } \\
\text { zone for } \\
18 \text { months }\end{array}$ & $\begin{array}{l}\text { Normal to } \\
\text { limit of } \\
\text { visibility }\end{array}$ & $\begin{array}{l}\text { Right middle } \\
\text { lobectomy }\end{array}$ & Good \\
\hline (4) 40 & $\begin{array}{l}\text { Persistent } \\
\text { cough and } \\
\text { dyspnoea }\end{array}$ & Normal & $\begin{array}{l}\text { Tumour at } \\
\text { origin of } \\
\text { right lower } \\
\text { lobe bronchus }\end{array}$ & $\begin{array}{l}\text { Bronchotomy, } \\
\text { excision, and } \\
\text { reconstruction } \\
\text { of bronchus }\end{array}$ & $\begin{array}{l}\text { Stenosis of } \\
\text { right main } \\
\text { bronchus }\end{array}$ \\
\hline (5) 45 & $\begin{array}{l}\text { Recurrent } \\
\text { cough and } \\
\text { haemoptysis }\end{array}$ & Normal & $\begin{array}{l}\text { Tumour } \\
\text { obstructing } \\
\text { bifurcation } \\
\text { of left upper } \\
\text { lobe bronchus }\end{array}$ & $\begin{array}{l}\text { Left upper } \\
\text { lobectomy }\end{array}$ & Good \\
\hline
\end{tabular}


The anatomical sites of each tumour are as shown in Fig. 1. All were easily seen at bronchoscopy with the exception of case (3).

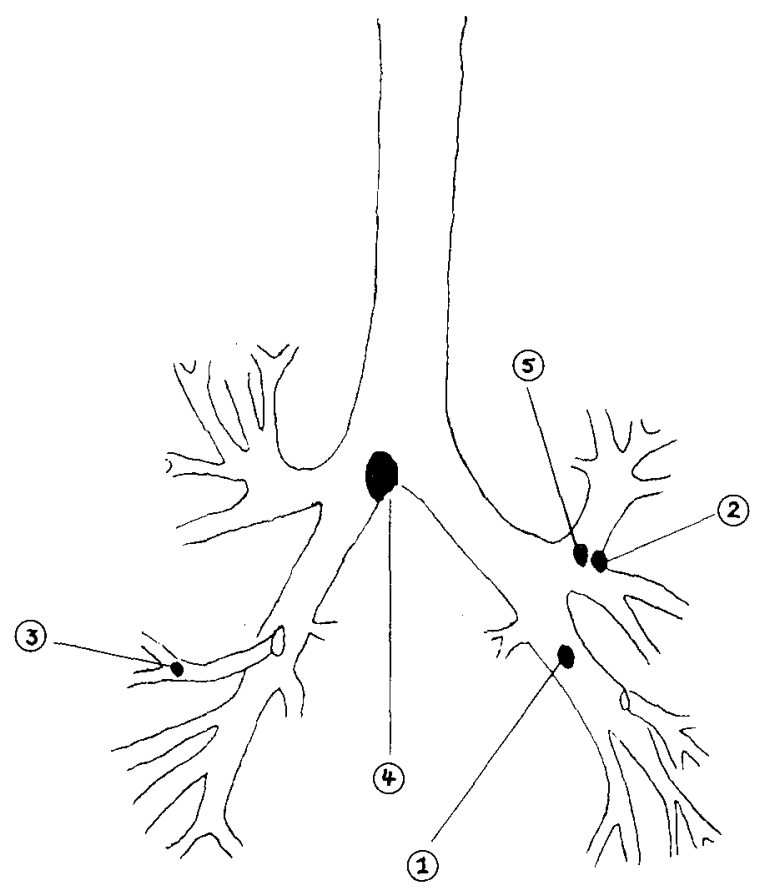

Fig. 1

In common with other series, no patient had features of the carcinoid syndrome either clinically or biochemically. The diagnosis of typical carcinoid tumour, made initially from the bronchoscopic biopsy, was in each case confirmed post operatively.

\section{Discussion}

Carcinoid tumour of the bronchus is rare in comparison with carcinoma. In one study, carcinoids comprised less than $2 \%$ of a series of 2200 consecutive lung tumours, ${ }^{1}$ and the mean age at diagnosis was 50 years. This very low figure is not our experience in the younger military population. At the Army Chest Unit, five carcinoids have been seen over the last two years in serving soldiers. During the same period only three bronchial carcinomas were seen.

The carcinoid tumour is now thought to have an extremely low degree of malignancy, although opinion has changed greatly over the years. After its initial description in 1930 , early studies held this view ${ }^{2}$, but doubt was cast in the $1960 \mathrm{~s}$, and by 1970 carcinoids were considered to be malignant tumours, albeit slow to grow and metastasise in comparison with carcinoma. The recommended surgical management became more aggressive. A study published in 1972 may be used as an example ${ }^{1}$. Twenty of the 27 cases underwent what was regarded as curative surgery; the procedures were seven pneumonectomies, two bilobectomies and 11 lobectomies. Four patients died post-operatively, and although no recurrence was seen in the remainder during the follow up period, these early deaths reduced the five year survival rate to $56 \%$.

More recently however fears about the malignant potential of the carcinoid have reduced again. There are two main reasons for this. The first is more accurate histological classification of the tumour. We have so far avoided using the term "bronchial adenoma". Although in the past this term was used synonymously with bronchial carcinoid, it should now be defined as a collective term for a group of tumours, of variable malignancy, of which the typical carcinoid is the most common and the most benign. Secondly, the discovery at operation of enlarged lymph nodes may have led to benign tumours being mistakenly labelled as malignant. Frozen section examination of nodes has shown that the great majority were enlarged because of inflammatory and not neoplastic causes. Carcinoid tumours, being endobronchial in origin, often obstruct bronchi and result in chronic distal sepsis, with subsequent lymphadenopathy.

Accurate preoperative histological diagnosis is important not only for differentiating within the adenoma group, but also for excluding oat cello carcinoma, the management of which is entirely different. Both types of tumour are thought to arise from the Kultschitsky or APUD (Amine Precursor Uptake and Decarboxylation) cell type, and can be confused if the biopsy is not satisfactory. If carcinoid is suspected, rigid rather than fibre-optic bronchoscopy is to be preferred. Carcinoids are usually situated in the main or lobar bronchi, and the extra range of the flexible scope is not required. A larger biopsy can be obtained through the rigid scope, and any subsequent haemorrhage from these vascular tumours can be more easily controlled.

A more recent study takes account of these findings, and regards curative surgery as local excision of the tumour with preservation of lung tissue if possible ${ }^{3}$. Chronic distal sepsis often made lobectomy unavoidable, but out of 57 procedures on 59 patients with typical carcinoids, there were eight segmentectomies or bronchotomies with tumour excision and reconstruction. No recurrence was seen in up to 18 years of follow up. In the whole series of 72 patients, the 10 year survival rate was 86 per cent. Similar results are described in a large series of 79 cases, virtually all of which were typical carcinoids ${ }^{4}$. These cases were collected over a period of 33 years, and management has become steadily more conservative since the mid 1970s. Lesser procedures have been carried out on 18 patients, and again no recurrences have been seen.

Clinical features, which in the young should raise suspicions of carcinoid tumour, are basically the same as 
those of carcinoma in the older age group. Our patients presented in ways which are also the most common in the larger series. Recurrent pneumonia, chronic cough and haemoptysis are all typical, as is the abnormal chest $\mathrm{X}$-ray in the asymptomatic patient. Chest X-ray is of no value in differentiating benign from malignant tumours ${ }^{4}$, and while tomography may be able to identify the bronchus from which the tumour has arisen, all of these patients deserve early referral for bronchoscopy and biopsy, the essential investigation. As two of our cases showed, even a normal X-ray should not defer bronchoscopy if the symptoms are suspicious.

In our own series, three patients required lobectomy because of the problem of chronic distal lung sepsis. One had a lobectomy because the tumour was peripheral and beyond the reach of the flexible bronchoscope. All of them made an excellent recovery with a return to normal exercise tolerance, and all have regained an unrestricted medical category. Patient No. 4 underwent bronchotomy and reconstruction as an alternative to pneumonectomy, because of the awkward position of the tumour. Unfortunately he developed bronchial stenosis which resulted in later lung collapse despite attempts at bronchoscopic dilatation. This is a reported complication of bronchotomy and reconstruction.
Carcinoid tumour of the bronchus appears to be a not3 uncommon lung tumour in the young military population. From the soldier's point of view, early suspicion, diagnosis and surgery should not only cure him, but also leave sufficient undamaged lung to enable? him to continue his career in a normal medical category. $\overrightarrow{\vec{A}}$

\section{Acknowledgement}

The authors would like to thank Mr Meredith-Brown $\overline{\overline{0}}$ for providing the surgical specimens and the pathologists at the Cambridge Military Hospital and the Royal Army Medical College for making histological diagnoses.

\section{REFERENCES}

1. Burcharth F and AxElsson C. Broncial Adenomas. Thorax 1972; 27 : 442-449.

2. Price-Thomas C. Benign tumours of the lung. Lancet 1954; 1 : 1 .

3. LAWSON R M, et al. Bronchial adenoma: review of an 18 year experience at the Bromton Hospital. Thorax 1976; 31: $245-252$.

4. Hurt $R$ and Bates M. Carcinoid tumours of the bronchus: a 33 year experience. Thorax 1984; 39: 이 617-623.

5. Giustra $P$ E and STASSA G. The multiple presentations $\underset{\Theta}{ } \mathrm{f}$ bronchial adenoma. Radiology 1969;93: 1013-1019. 